\title{
Visa-Free Travel to Sri Kartarpur Sahib: Historic Pilgrimage and Religious Tourism from Indian Punjab to Pakistan Punjab
}

\author{
Taranjeet Kaur Chawla, ${ }^{1}$ Rayaz Hassan, ${ }^{2}$ \& Daljeet Kaur ${ }^{3}$ \\ ${ }^{1} \mathrm{PhD}$ Research Scholar, Department of Journalism and Mass Communication, Manipal \\ University Jaipur, Rajasthan-India. ORCID id: oooo-0oo2-5336-1964. \\ Email id:ms.kauron@gmail.com \\ ${ }^{2}$ Associate Professor \& Head of the Department, Department of Journalism and Mass \\ Communication, Manipal Universirty Jaipur, Rajasthan-India. \\ Email id: rayaz.hassan@jaipur.manipal.edu \\ ${ }^{3}$ Assistant Professor, Department of Community Medicine, Government Medical College, \\ Pali, Rajasthan-India. Email id: drkaur247@gmail.com
}

\begin{abstract}
Kartarpur, the holiest shrine in Sikhism located across River Ravi in Pakistan, was founded in 1504 CE by Guru Nanak, the first guru of Sikhism, who also established the first Sikh commune there. This time, the 55oth birth anniversary of Guru Nanak was celebrated as the road to prosperity of the region. In November 2019, the government of India and Pakistan opened a Kartarpur corridor linking two significant Sikh shrines, namely Sri Dera Baba Nanak Sahib located in Indian Punjab and Gurudwara Darbar Sahib, located in Kartarpur, Pakistan. The visa-free travel of Sikh pilgrims through the Kartarpur corridor became a historic pilgrimage for both countries. Earlier scholarly research focused on symbolism, politics and impact on India-Pakistan relations with the construction of the Kartarpur corridor. The present study aims to examine the significance of the Kartarpur corridor among Sikh devotees and explores how Kartarpur as a site for religious tourism develops the region's economic growth and boosts the tourism industry on both sides. Adopting a mixed methodology, the study collected data through quantitative and qualitative research methods with primary and secondary sources followed by data analysis. It tries to establish symbolic importance of the Kartarpur as historic pilgrimage and religious tourism to generate economic connectivity between both countries and offers overarching importance at both national and international levels.
\end{abstract}

Keywords: Economic connectivity, Historic pilgrimage, Kartarpur corridor, Religious tourism.

\section{Introduction}

This paper examines the significance of the Kartarpur corridor among Sikh devotees. The year 2019 marked the $550^{\text {th }}$ birth anniversary of Guru Nanak when the Kartarpur Corridor was inaugurated by India's Prime Minister and Pakistan's Prime Minister, in their respective countries (BBC News, 9 November, 2019). After several years of efforts, Government of India has succeeded in facilitating pilgrimage of devotees to Sri Kartarpur Sahib. Pilgrimage refers to a journey that is motivated by religion or spirituality and plays a significant role in almost all world religions. In India, one of the most important pilgrim centres in Amritsar (Sri Harmandir Sahib) attracts pilgrims from all over the world. India is a country of religious diversity and the Sikh pilgrimage (C) AesthetixMS 2020. This Open Access article is published under a Creative Commons Attribution Non-Commercial 4.0 International License (http://creativecommons.org/licenses/by-nc/4.0/), which permits non-commercial re-use, distribution, and reproduction in any medium, provided the original work is properly cited. For citation use the DOI. For commercial re-use, please contact editor@rupkatha.com. 
plays an important role in generating mass tourism. Survey conducted by Rajinder S. Jutla mentioned that 90 percent of his respondents identified the Harmandir Sahib as the most "important sacred site" (Jutla, 2016).

In November 2018, the governments of India and Pakistan agreed to open a corridor over the River Ravi linking two important Sikh shrines -- Dera Baba Nanak in India with Gurudwara Darbar Kartarpur Sahib in Pakistan. The opening of the Kartarpur corridor was an event in history that changed the tone of pessimistic analytical op-eds on both sides at least transiently if not permanently (Firstpost, November, 2018).This time, the 55oth birth anniversary of Guru Nanak was celebrated as the road to prosperity of the region. Kartarpur, the holiest shrine in Sikhism was founded in 1504 CE by Guru Nanak, the first guru of Sikhism, and is located across River Ravi in Pakistan. He also established the first Sikh commune there (Singh, Jagraj 2009). The ideal community of Kartarpur, where Guru Nanak lived, is now honored by a Gurudwara that contains his mortal remains interred in accordance with both Hindu and Muslim practice. Gurudwara Dera Baba Nanak is about one km from the Indo- Pakistan border and on the east bank of River Ravi. To the west side of the river is located the town of Kartarpur, Pakistan. Gurudwara Sri Kartarpur Sahib falls in the district of Narowal in Pakistan. It is about $4.5 \mathrm{~km}$. from the international border near the historic town of Dera Baba Nanak in the Gurdaspur district of Punjab in India which the followers of Guru Nanak built and named after him. Sri Kartarpur Sahib Corridor involves a $4.1 \mathrm{~km}$. long four lane highway from Dera Baba Nanak to the international border and a state of the art Passenger Terminal Building (PTB) at the international border.

Several researchers (G. Singh 2019; A. H. Sandhu 2019; Harisimran Singh 2019; A. Shukla 2019; Iqbal Singh 2018; A. Z. Kamboh et al. 2018) have attempted to explore the relevance of the Kartarpur Corridor. Gurharpal Singh examined critically the efforts to control and manage Sikh shrines in Pakistan from the Partition to the Kartarpur corridor access since 1947. Harsimran Singh has written his book on the Kartarpur model of coexistence of world cultures and helps in grasping the import of Guru Nanak's all-embracing and all-inclusive philosophy and undercurrents of the Kartarpur Model envisaged by the Guru. A. H. Sandhu studied Kartarpur corridor's divergent dimensions and its impact on Pakistan and India. He mentioned that the Kartarpur corridor, being a revolutionary step, will cast a tremendous impact on the politics of India and social setup of Pakistan being situated on the Pakistan-India border. Iqbal Singh examined the significance of the Kartarpur Corridor and the politics that undergirds its construction. He also analysed the issues and challenges that have to be resolved before the corridor can be opened. A. Z. Kamboh et al. study the role of political communication in the Kartarpur corridor and also mention that its opening is a landmark step in international political marketing.

Rajinder S. Jutla focused on understanding Sikh pilgrimage and he examined the role of pilgrimage in Sikh scriptures along with investigating the reasons why so many Sikhs travel to sacred sites. In the chapter entitled “What are Sikhs doing at "Historical Gurudwaras” If They're Not on Pilgrimage? A.M. Pinkney (2018) illustrated the relationship between narrative texts and sites with selections from some of the most well-known Janam Sakhi episodes and the contemporary Sikh religious places associated with them, both at SGPC (Sriromani Gurudwara Prabandhak Committee) and non-SGPC properties. The present study attempts to bridge the gap by examining the significance of the Kartarpur corridor in terms of historical pilgrimage to Sri Kartarpur Sahib. It begins with a brief background of Sri Kartarpur Sahib in terms of history and religious beliefs and then explores the genesis of the Kartarpur corridor. It also tries to establish symbolic importance of Kartarpur as historic pilgrimage and religious tourism to generate 
economic connectivity between both countries and offers overarching significance at national and international level.

\section{The Historical and Religious Significance of Sri Kartarpur Sahib}

The first guru of Sikhism, Guru Nanak (15 April 1469 - 22 September 1539) travelled along with Bhai Mardana who carried and played the rabab (music instrument) through many countries (Udasis) spreading the message of one God who dwells in every one of His creations and constitutes the eternal Truth before finally arriving in Kartarpur in 1521 (Hayer, 1988, p. 14). Duni Chand, who was the Governor of the area was fortunate to met Guru Nanak and he donated land around 100 acres to Guru Sahib (Sharma, 2019). On the Guru's acceptance of the land he decided to settle there and a small building was constructed. In Kartarpur, the Guru "shed his travelling garb and adopted the dress of a simple household and farmer". In the words of professor Puran Singh, a prominent 2oth century Punjabi poet and scientist, the Guru "radiated love and faith and attracted people like light attracts moth" in Kartarpur (Sarna, 2019).

After having spent a lifetime of travelling and setting up missions, around the age of 55 Nanak settled in Kartarpur, and lived there until his death in September 1539 at the age of seventy. While living in Kartarpur, Guru Nanak spread a message to the community- Kirt Karo (Do Work), Naam Japo (Do Meditate) and Vand Chako (Share in charity). Guru Angad (2nd Guru in Sikhism) was appointed as the successor Guru by Guru Nanak. The foundation stone of the Gurudwara in Kartarpur was laid in 1572 and Maharaja Ranjit Singh covered its dome with gold. The present structure was built by Bhupinder Singh, the Maharaja of Patiala in 1925 and grandfather of Punjab's chief minister Captain Amarinder Singh (Singh, V., 2018). With the rejection of caste, icon-worship and empty ritual, Sri Kartarpur sahib became a holy shrine of Sikhism.

\section{The Genesis of the Kartarpur Corridor}

The Kartarpur corridor leads to one of the holiest sites in the Sikh religion. A historic corridor to one of Sikhism's holiest shrines- which is in Punjab, a region divided during the partition of British India in 1947 is opened in November, 2019, allowing Indian pilgrims rare visa-free access to the site in Pakistan (BBC News, 9 November, 2019). The Gurudwara Darbar Sahib, Kartarpur as a historic pilgrimage refers to a journey that is motivated by religion or spirituality and plays a significant role in almost all Sikhs. With the Kartarpur initiative, it could be conceivably time to overcome the feeling of rightful indignation regarding the politically-strained and historicallycharged relationship between India and Pakistan (EFSAS, November 2019). The opening of the Kartarpur Corridor with the joint efforts of two rival nations, India and Pakistan is not only, a corridor merely to visit Gurudwara Sahib to pay obeisance there but also, has inherent potentialities to herald a new world order wherein mutual differences are erased to make way for cultural co-existence and harmony in the Indian sub-continent (H. Singh, 2019). UN chief Antonio Guterres visited the Gurudwara Darbar Sahib and said that the opening of the Kartarpur Sahib Corridor is a practical example of Pakistan's desire for peace and inter-faith harmony (The Economic Times, 18 February 2020). 


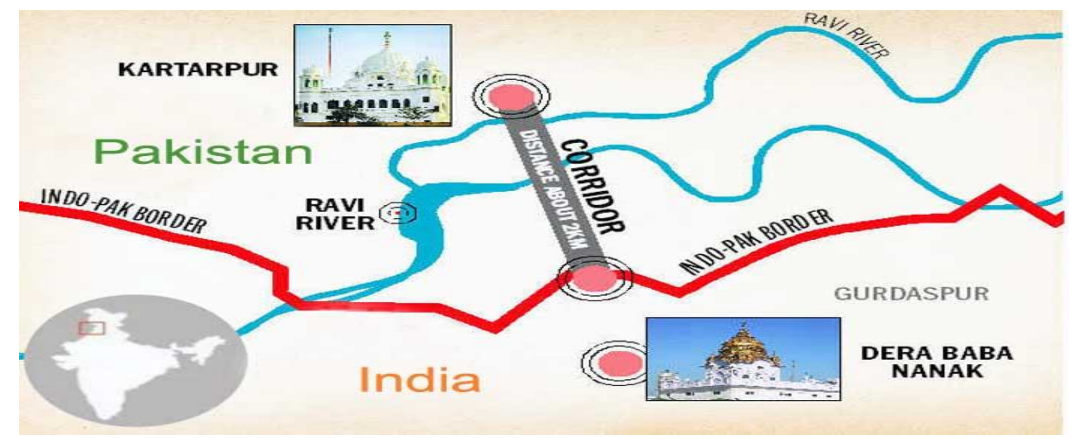

Source: Ministry of Home affairs (prakashpurab555.mha.gov.in/kpr/)

Below is the chronology of the Kartarpur Corridor (1999 to 2019) compiled from secondary sources:

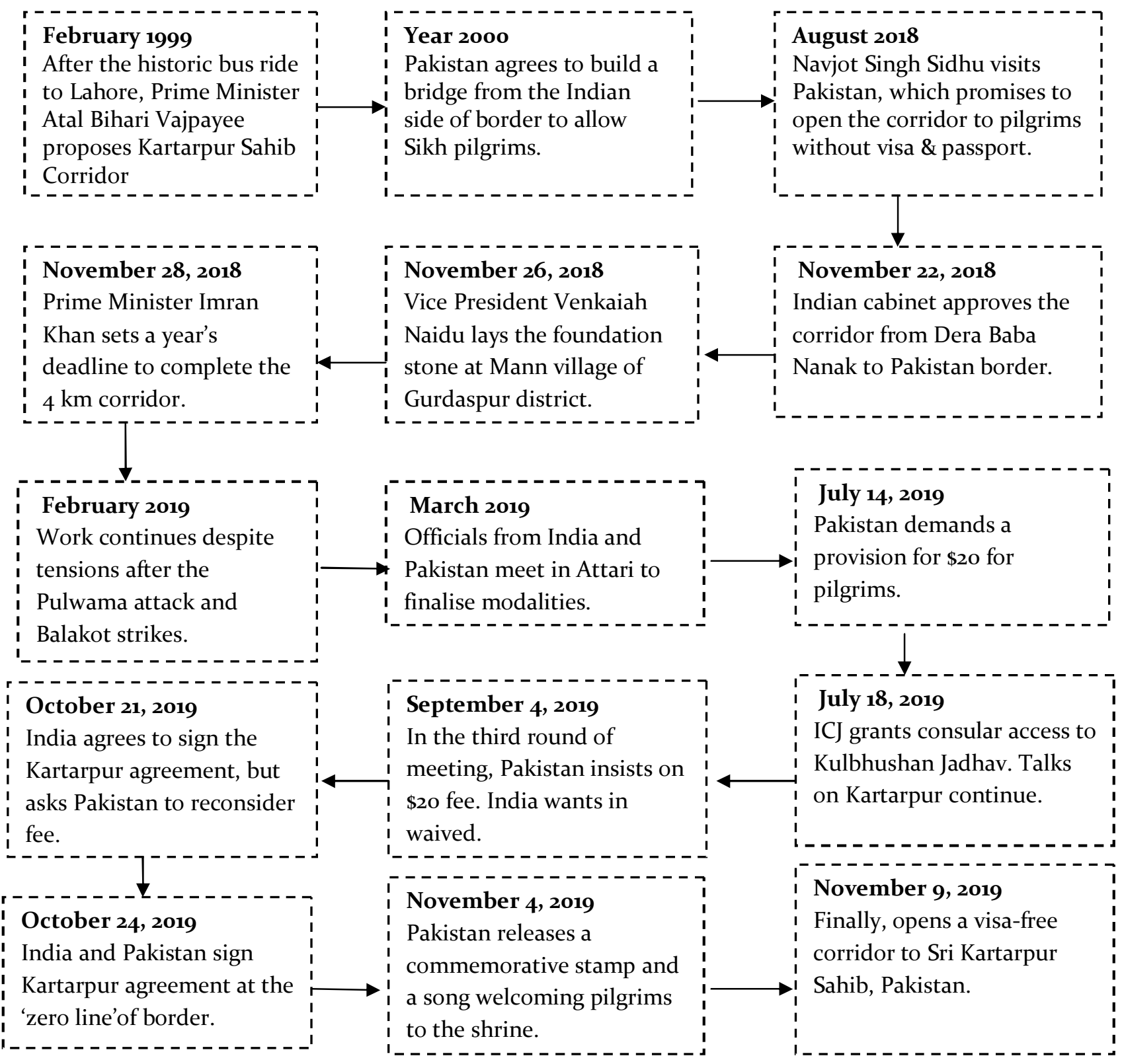




\section{Methodology}

Primary data collection has been accomplished through survey method. Questionnaire which included Likert scale as an orderly scale from which respondents selected the option that best supports their opinion.

To explore the significance of the Kartarpur corridor among Sikhs a questionnaire was administered to 250 pilgrims at major pilgrim centres, the Gurudwara Sahib in Delhi (Gurudwara Sri Bangla Sahib, Gurudwara Sis Ganj Sahib and Gurudwara Shri Rakab Ganj Sahib).This was done randomly over a two-week period in February 2020 by researchers who are fluent in Punjabi, English and Hindi. The sample consisted of Sikh devotees over age 25, with at least a high school education and knowledge about Sikh history. It comprised a wide range of occupations, including self- employed businessmen, private employees, artisans, doctors, engineers, lawyers and educators.

The survey has been followed by the data collection from secondary sources which included research article, thesis, books, new articles and official websites. The researcher used Microsoft Office Excel 2010 to analyze the primary data collection.

\section{Significance of Kartarpur Corridor among Sikh devotees}

In response to a question about the importance of Kartarpur corridor among Sikh devotees, the study revealed that 47.2 percent of the Sikh devotees believed that the Kartarpur corridor is very important as it leads to one of the holiest sites in the Sikh religion and 28.8 percent feels it is important. They expressed knowledge that the Sri Kartarpur Sahib is relevant with the founder of Sikhism, Guru Nanak's life so it encourages them to visit at least once. 12 percent and 7.2 percent however felt moderately and slightly important about this and the remaining 5 percent believed that it is not important at all to visit as a pilgrim (Figure 1).

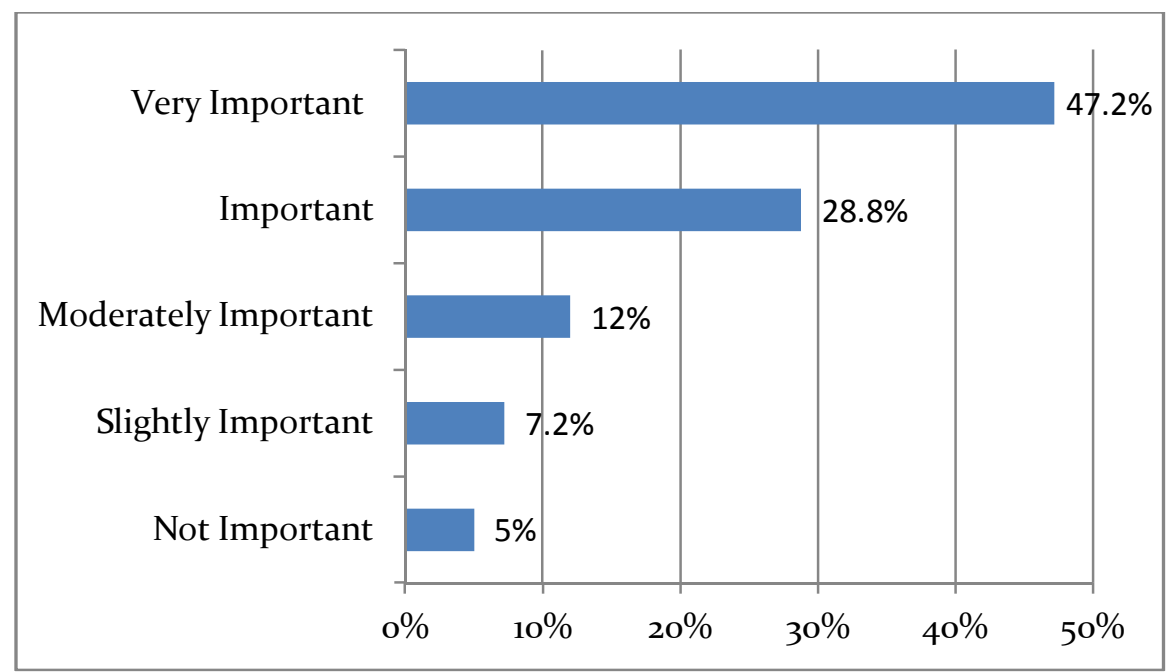

Figure 1: Importance of Kartarpur Corridor among Sikh Devotees

Almost 40 percent of the Sikhs devotees surveyed were local to the area while the remaining 60 percent came from other cities, states, and countries. In response to the queries about whether the mode of transportation was helpful to reach Sri Kartarpur sahib via the corridor, 37 percent and 26 percent so, in all 63 percent feels the transportation is extremely helpful and very helpful 
(Figure 2). According to Indian Railways information, there are around 25 trains from Delhi to Dera Baba Nanak Railway station; Dera Baba Nanak Railway station is located near the ICP, Kartarpur Corridor and this station provides free WiFi facilities for pilgrims (Sinha, 2019).

Respondents were asked about when they generally travel to historical pilgrimages. 29 percent stated that they prefer to visit on Gurupurabs (the Festival of Guru). 41 percent reported that they usually visit during vacations. The 18 percent prefer travelling in groups which were arranged by Gurudwara Management Committees (GMC) every year. The remaining 12 percent visit historical pilgrimage every two to five years.

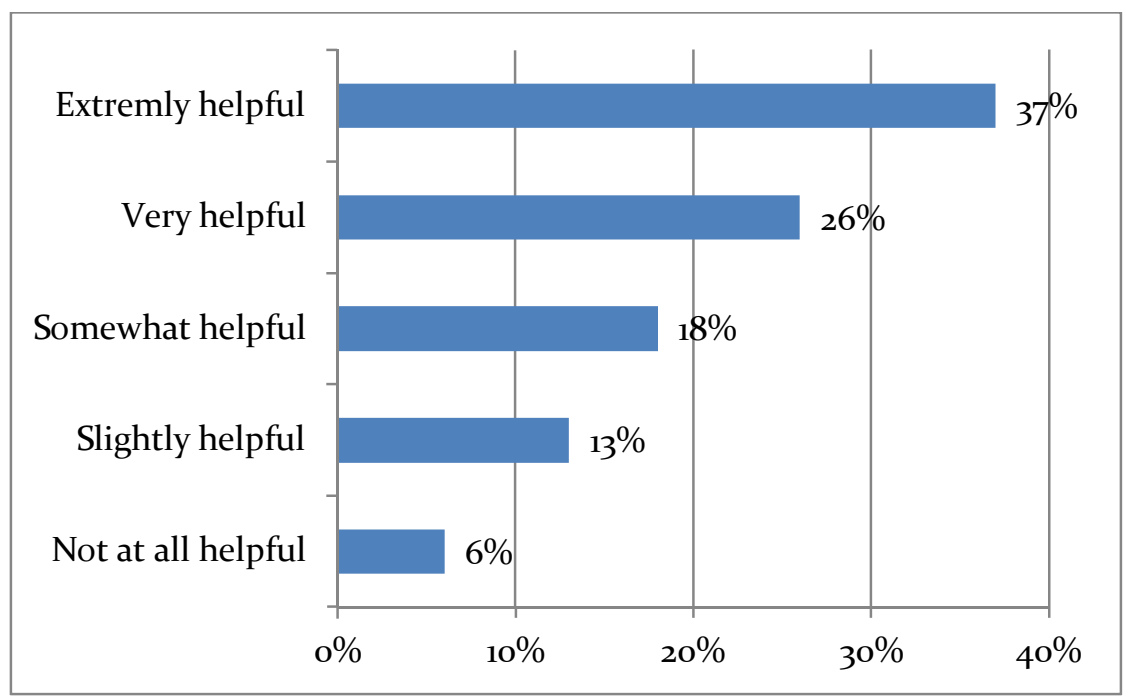

Figure 2: The mode of transportation helpful to reach Sri Kartarpur sahib via corridor

Participants were asked about the awareness of the website which is run by Ministry of Home affairs (prakashpurab555.mha.gov.in/kpr) for Pilgrimage to Sri Kartapur Sahib. 24 percent said they have heard about the same in the announcements made by Gurudwara Management Committees, 26 percent reported that they got to know from social media platforms. The 12 percent were aware through the website and 15 percent however were unsure about this and the remaining 23 percent reported that they came to know through word of mouth publicity.

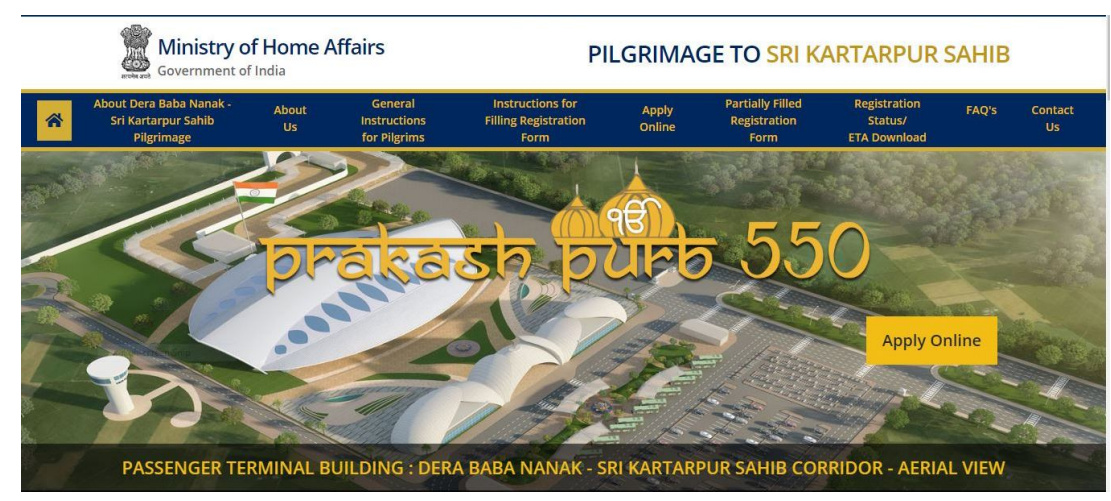

Image 1: website- Ministry of Home affairs prakashpurab555.mha.gov.in/kpr

Visitors were also asked about their reasons for wishing to visit Sri Kartarpur Sahib in Pakistan. They were provided with four choices and asked to identify any number that was appropriate to them. The analysis showed that Sikhs go on this pilgrimage for many reasons. 49 percent stated that they would love to visit for spiritual reasons, whereas 30 percent wish to visit due to 
historical significance because this place is related to the founder of Sikhism, Guru Nanak. Sikhs also believed that it is important to visit with their children to connect with Guru, Sikh history and values. 15 percent stated that they want go for request to solve problems in their life. 6 percent said they want to make a wish at that Gurudwara Sahib (Figure 3).

It was informed by Union Minister of State for Home G Kishan Reddy in the Lok Sabha that since the opening of the Kartarpur corridor's route in November 2019, a total of 44, 951 pilgrims travelled from 9 November 2019 to 31 January 2020 through this corridor (The Economic Times, 11 February, 2020).

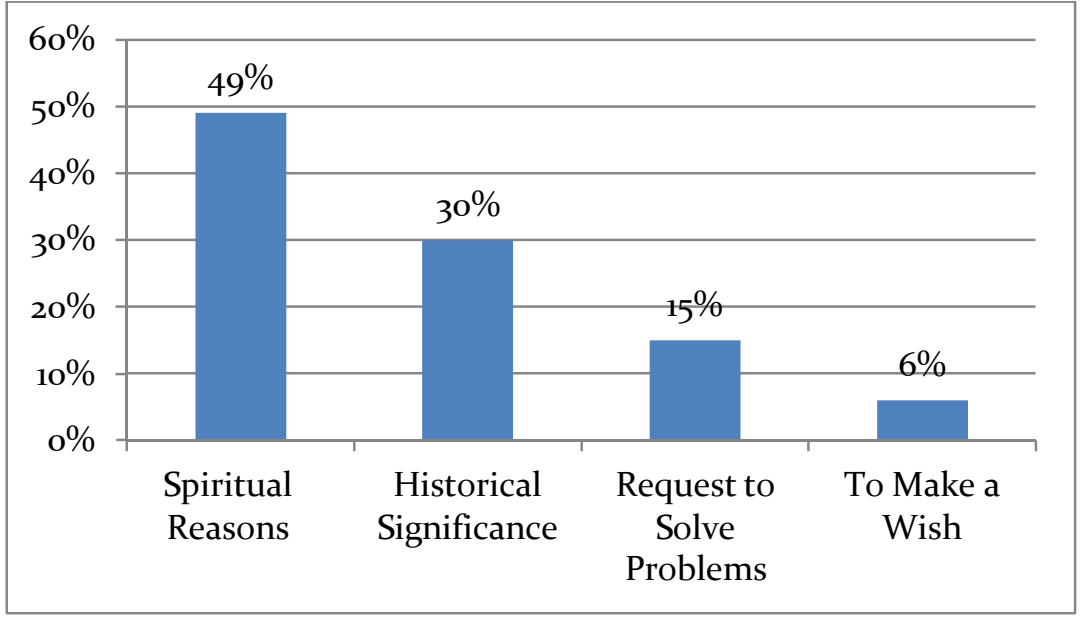

Figure 3: Reasons for wish to visit to Pilgrimage to Sri Kartarpur Sahib

In response to the question regarding the booking and accommodation facilities at the place of pilgrimage, it was discovered 31 percent check official website of the place to find out the detailed information to make room reservation online. 36 percent prefer to book offline in the Gurudwara accommodation. 19 percent visit online website to book hotels for their stay near the pilgrimage place. The remaining 14 percent prefer relative's place for their stay.

In response to whether the statement of opening of Kartarpur Corridor was practical proof of Pakistan's desire for peace and whether it will promote tolerance and interfaith harmony, the respondents expressed strong agreement 16.03 percent and agreement 39.02 percent (Figure 4).

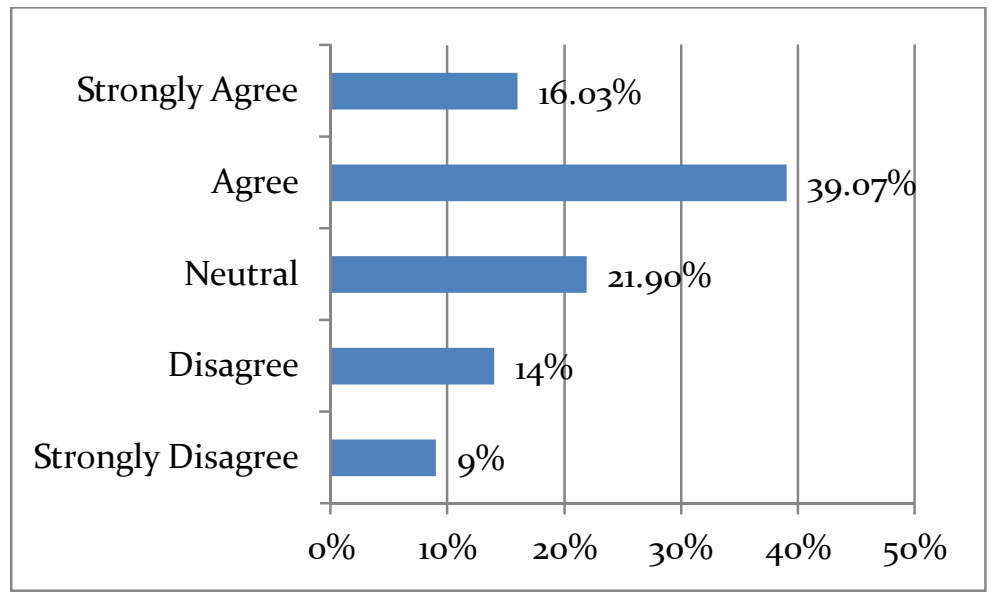

Figure 4: Opening of Kartarpur Corridor practical proof of Pakistan's desire for peace 
Respondents were asked whether they had visited and chose to visit historical Gurudwara sahibs in future. A list of seven historical Gurudwara sahibs in Pakistan was given and respondents were asked to indicate their choices (Table number 1). Gurudwara Nankana Sahib, Gurudwara Darbar Sahib, Kartarpur and Gurudwara Panja Sahib, were overwhelmingly identified as the most important places in the wish list. Due to visa free travelling via Kartarpur Corridor, 91 percent Sikh devotees wished to visit Sri Darbar Sahib, Kartarpur and remaining 9 percent have already visited in November 2019. Gurudwara Lal Khooli (The Bloody Well) is related to the 5th Guru, Arjan Dev and Gurudwara Janam Asthan Guru Ram Das is significant because of the birth place of the 4th Guru. Gurudwara Shaheed Bhai Taru Singh was made in the memory of Bhai Taru Singh where he was martyred.

A total of 562 Indian pilgrims and tourists visited Kartarpur Sahib on November 9, the day the corridor was launched by Prime Minister Narendra Modi from the Indian side (Gupta, 2019).

Table 1: The Historical Gurudwara Sahib in Pakistan that Sikh Devotees Wish to Visit in the Future

\begin{tabular}{|c|c|c|}
\hline $\begin{array}{l}\text { Sr. } \\
\text { No. }\end{array}$ & $\begin{array}{l}\text { Which historical Gurudwara Sahib you would like to visit in the next } \\
\text { few years? More than one percentage response was possible. }\end{array}$ & $\begin{array}{l}\text { Response } \\
\text { in } \\
\text { percentage }\end{array}$ \\
\hline 1. & $\begin{array}{l}\text { Gurudwara Nankana Sahib in Nankana Sahib (The birthplace of the } \\
\text { founder of Sikhism) }\end{array}$ & $86 \%$ \\
\hline 2. & $\begin{array}{l}\text { Gurudwara Panja Sahib, Hasan Abdal (The handprint of the founder of } \\
\text { Sikhism, Guru Nanak) }\end{array}$ & $83 \%$ \\
\hline 3. & $\begin{array}{l}\text { Gurudwara Darbar Sahib Kartarpur Shakargarh, Narowal (Guru Nanak, } \\
\text { settled and assembled the Sikh community after his missionary travels) }\end{array}$ & $91 \%$ \\
\hline 4. & $\begin{array}{l}\text { Gurudwara Chowa Sahib (Gurudwara of the exalted spring) Rohtas } \\
\text { Fort, near Jhelum, Pakistan. }\end{array}$ & $79 \%$ \\
\hline 5. & $\begin{array}{l}\text { Gurudwara Lal Khoohi (The Bloody Well) Lahore, Pakistan (The fifth } \\
\text { Sikh Guru, Guru Arjan Dev, was incarcerated during the reign of the } \\
\text { Mughal Emperor, Jehangir) }\end{array}$ & $77 \%$ \\
\hline 6. & $\begin{array}{l}\text { Gurudwara Janam Asthan Guru Ram Das Lahore, Pakistan. (The } \\
\text { birthplace and childhood home of Guru Ram Das, the } 4 \text { th Sikh guru) }\end{array}$ & $80 \%$ \\
\hline 7. & $\begin{array}{l}\text { Gurudwara Shaheed Bhai Taru Singh in Lahore, Pakistan (which } \\
\text { commemorates the spot where Bhai Taru Singh was martyred) }\end{array}$ & $78 \%$ \\
\hline
\end{tabular}

\section{Kartarpur as Religious Tourism and Economic Connectivity}

According to the official agreement which has been signed between India and Pakistan on 24 October 2019, five thousand visitors were permitted visa free entry daily to the holy Sikh shrine (Aljazeera, 10 November 2019). Visitors will be charged approximately rupees 1,400 for their visit (Sharma, 2019). To help the pilgrims, the state government has provided service facilitation centres. Punjab Minister for Jails and Cooperation Sukhjinder Singh Randhawa stated that, "The state government has already opened doors of its e-Sewa Kendras for the devotees wanting to use 
Kartarpur corridor. The registration form of the aspiring pilgrim is filled here free-of-cost." (qtd. In Gupta, 2019).

The approach of the Kartarpur Corridor can also help to understand the procedure of 'tourismpilgrim' and facilitate the current tourism industry with the expression of a pilgrimage tradition. As per the registration process this journey is visa-free but Electronic Travel Authority document known (ETA) is required, which can be obtained by registering an application at online website (prakashpurb550.mha.gov.in). Detailed information and instructions are given on this website which have to be followed by all Indian pilgrims.

Though the route of Kartarpur corridor may connect peace and prosperity among both countries, it also brings the route of religious tourism for Pakistan. For example, Sri Harmandir Sahib (Golden Temple) in India attracts around million of pilgrims every year due to historical and religious significance, so Sri Kartarpur Sahib which is called the first Gurudwara in the world, which has been established by Guru Nanak, indicates the potential gains from the Sikh holy shrine as religious tourism. A study commissioned by World Bank's task team estimated that if proper facilities were provided and marketing efforts made, tourism could exceed 300,ooo persons per year which could yield economic benefits of up to $\$ 300$ million per year. The opening of Kartarpur corridor is a step in that direction (Business Recorder, December, 2018).

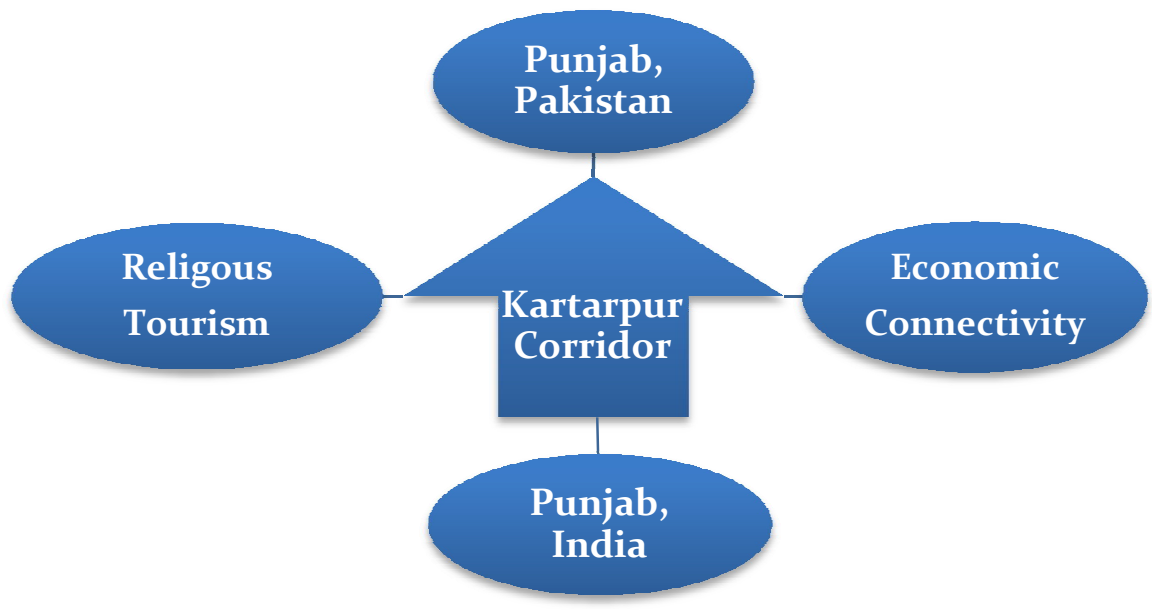

Figure 5: Connectivity from Punjab, India to Punjab, Pakistan via Kartarpur Corridor

(Conceptual framework based on the Literature review and preliminary study)

However, there will be economic benefits of Kartarpur for Pakistan. The governor of Pakistan's eastern Punjab province has even claimed that religious tourism in the country could bring in \$5 billion into the country every year. There are over twenty Gurudwara Sahibs in Pakistan which carries spiritual importance for pilgrimage, acknowledged by Sikh Community members. For religious tourism to flourish, an overarching national level tourism promotion strategy has to be implemented by the Pakistan government (Ahmed, 2019). According to official sources, Punjab (Pakistan) government and Federal Government of Pakistan are also working to construct a motorway between Sialkot International Airport to Gurudwara Darbar Sahib Kartarpur Corridor Complex for catering to international traffic of tourists and Sikhs (Dispatch News Desk, 18 March, 2019). 


\section{Conclusion}

The present study has examined the significance of Kartarpur corridor among Sikh devotees and tried to establish the symbolic importance of Kartarpur as historic pilgrimage and religious tourism to generate economic connectivity between both countries. The Bani (words) of Guru Arjan Dev ( $5{ }^{\text {th }}$ Guru in Sikhism) says, 'God's name is the real of pilgrimage and pilgrim stations are the Name's meditation and the inner divine knowledge' (Guru Granth Sahib: 687) Despite not being compulsory, Sikhs still visit historical Gurudwara sahib for spiritual, historical and other significant reasons. The Kartarpur corridor as visa-free travel has become the way to fulfill their wish to visit the historical pilgrimage in Pakistan. The study therefore concludes that the economic connectivity and religious tourism via Kartarpur corridor provides traditional pleasurebased tourism activities among Indian Punjab and Pakistan Punjab. The holy Sikh shrine plays a vital role in social, religious, and economic connectivity between both the countries and offers overarching significance at national and international levels.

\section{Acknowledgments}

The researchers gratefully acknowledge the Management Committee of Delhi Gurudwara Sahib for allows us to conduct survey in the premises of Gurudwara Sahib.

\section{References}

Aljazeera. (2019). "Big moment: Indian Sikhs on historic pilgrimage to Pakistan."

November 10. https://www.aljazeera.com/news/2019/11/indian-sikhs-historic-pilgrimage-pakistan191109074815589.html

Ahmed. V. (2019, November 17). "The economics of Kartarpur and religious tourism." Arab News Pakistan. https://www.arabnews.pk/node/1585376

Baker, Janet. (2019). “Guru Nanak: 55oth birth anniversary of Sikhism’s founder."

Sikh Formations 15:3-4, 495-515 DOI: 10.108o/17448727.2019.1685641

$B B C$ News. (2019). "Kartarpur corridor: India pilgrims in historic visit to Pakistan temple." November 9. https://www.bbc.com/news/world-asia-india-50342319

Business Recorder. (2018). 'Kartarpur religious tourism potential.' December 5. https://www.brecorder.com/2018/12/05/456784/kartarpur-religious-tourism-potential/

Dera Baba Nanak. http://derababananak.com/darbarsahib_derababananak.htm

Dispatch News Desk. (2019). Design and map of Gurdwara Darbar Sahib Kartarpur Corridor Complex. March, 18. https://dnd.com.pk/design-and-map-of-gurdwara-darbar-sahib-

EFSAS (2019). "A flicker of light at the end of Kartarpur Corridor." European Foundation for South Asian Studies. Amsterdam.

Sinha, D. (2019, November 15). "Big boost for Kartarpur Corridor pilgrims! Indian Railways provides free WiFi at Dera Baba Nanak Station, ICP.” Financial Express. https://www.financialexpress.com

Firstpost. (2018). "Kartarpur Corridor: Visa-free pilgrimage route a good confidence-building measure, but thaw in India-Pakistan ties still a mirage." November 30. https://www.firstpost.com

Grewal, J.S. (1998). The Sikhs of the Punjab. The New Cambridge History of India (Revised ed.). Cambridge University Press. 
Guru Granth Sahib. p. 687 https://www.sikhnet.com/Siri-Guru-Granth-Sahib

Hayer, Tara. (1988). Economic History of Sikhs: Sikh Impact. Surrey, Canada: Indo-Canadian Publishers, Volume 1.

Gupta, S. (2019, November, 18). "Pilgrims grow at Kartarpur, Sunday to see 1,80o visitors." Hindustan Times. https://www.hindustantimes.com/india-news/pilgrims-grow-at-kartarpur-sunday-to-

Jutla, Rajinder S. (2002). “Understanding Sikh Pilgrimage”. Tourism Recreation Research, 27:2, 65-72. DOI10.1080/02508281.2002.11081222.

Jutla, Rajinder S. (2016). "The Evolution of the Golden Temple of Amritsar into a Major Sikh Pilgrimage Center." Geosciences 2 (3): 259-272.

Kamboh Amir Z., Kamal Yasir et al. (2018). "Kartarpur Corridor: A New Role for Political Marketing." Journal of Indian Studies Vol. 4, No. 2, pp. 233-238.

Ministry of Home Affairs. 'pilgrimage to kartarpur sahib.' https://prakashpurb55o.mha.gov.in/kpr/

Nesbitt Eleanor M., and Gopinder Kaur. (1998). “Guru Nanak”. Bayeux Arts. p. 15.

Pinkney A.M. and Whalen-B. J. (2018). Religious Journeys in India Pilgrims, Tourists, and Travelers. Albany: State University of New York Press.

Sandhu, Akhtar H. (2019, February). 'Kartarpur Corridor: Divergent Dimensions and its

Impact on Pakistan and India'. https://www.researchgate.net/publication/331064178_

Sevea, Iqbal S. (2018). “The Kartarpur Corridor: Symbolism, Politics and Impact on India-Pakistan Relations." Institute of South Asian Studies. No. 525.

Singh, Gurharpal. (2019). "The control of sacred spaces: Sikh shrines in Pakistan from the partition to the Kartarpur corridor.” Sikh Formations. DOI:10.1080/17448727.2019.1593305

Singh, Harisimran. (2019). Vismadi Samajic- Satta Prabandh Di Dastak: Visvav Sbhiacharya Di Sarhond Da Kartarpuri Model (Advent of Vismadi World Order: Kartarpuri Model of Coexistence of World Cultures). Punjab: Lokgeet Prakashan.

Singh, H. S. (2000). The Encyclopedia of Sikhism. Hemkunt Press.

Singh, Jagraj. (2009). A Complete Guide to Sikhism. Unistar Books.

Shukla, A. (2019, April, 10). "The Politics of Kartarpur Corridor and India-Pakistan Relations." Indian Council of World Affairs.

The Economic Times. (2020, February 18). "Opening of Kartarpur Corridor practical proof of Pakistan's desire for peace, says UN chief.” https://economictimes.indiatimes.com/news/international/worldnews/opening-of-kartarpur-corridor-practical-proof-of-pakistans-desire-for-peace-sayschief/articleshow/74192554.cms

The Economic Times. (2020, February 11). "Nearly 45,00o pilgrims visited Kartarpur Sahib since Nov 2019." https://economictimes.indiatimes.com/news/politics-and-nation/nearly-45000-pilgrims-

Sharma, U. (2019, November 9). "The religious and historical significance of Kartarpur Sahib gurdwara” The Print. https://theprint.in/theprint-essential/the-religious-and-historical-sig

Singh, V. (2018, November 28). "Patiala royal got historic Gurdwara rebuilt in 1920s. The Tribune. https://www.tribuneindia.com/news/archive/punjab/patiala-royal-got-historic- gurdwara-rebuilt-in1920s-690543

Sarna, N. (2019, July 13). "What Kartarpur Symbolises for Guru Nanak, and for Sikhism Today." TheWire. https://thewire.in/culture/guru-nanak-birth-anniversary-kartarpur 